\title{
Effect of Sowing Methods and Seeding Rates on Growth, Yield and Yield Components of Tef (Eragrostis Tef) in Ebinat Districts, South Gondar, Ethiopia
}

\author{
Sisay Tefera ${ }^{1, *}$, Getachew Alemayehu², Abebe Zeleke ${ }^{3}$ \\ ${ }^{1}$ College of Agricultural and Environmental Science, Bahir Dar University, Bahir Dar, Ethiopia \\ ${ }^{2}$ Agricultural Transformation Agency (ATA), Addis Ababa, Ethiopia \\ ${ }^{3}$ Faculty of Agricultural and Environmental Science, Debre Tabor University, Debre Tabor, Ethiopia \\ Email address: \\ Sisayt97@gmail.com (S. Tefera), getachewalemayehu.64@gmail.com (G. Alemayehu), az.abebe49@gmail.com (A. Zeleke) \\ ${ }^{*}$ Corresponding author
}

To cite this article:

Sisay Tefera, Getachew Alemayehu, Abebe Zeleke. Effect of Sowing Methods and Seeding Rates on Growth, Yield and Yield Components of Tef (Eragrostis Tef) in Ebinat Districts, South Gondar, Ethiopia. International Journal of Science, Technology and Society. Vol. 9, No. 3, 2021, pp. 142-148. doi: 10.11648/j.ijsts.20211003.15

Received: April 2, 2021; Accepted: May 27, 2021; Published: June 22, 2021

\begin{abstract}
The study was conducted during 2013/14 main cropping season in Ebinat district with the aim of studying the effects of seeding rates and row sowing methods on growth, yield and yield components of tef. Planting material of improved tef variety 'Quencho' (DZ-01-387) was used as a test crop for the experiments. Two factors of 3 seeding rates of $(5,7.5 \& 10 \mathrm{~kg} / \mathrm{ha})$ and 3 inter-row spacing of $(15 \mathrm{~cm}, 20 \mathrm{~cm} \& 25 \mathrm{~cm})$ were combined to form 9 treatment. The treatments were laid out in randomized complete block design (RCBD) with three replications. Days to $50 \%$ emergence, days to $50 \%$ heading, days to $90 \%$ physiological maturity, plant population. Total tiller number per plant, effective tiller, plant height, panicle length, number of spikelet's per panicle, biomass and straw yield, thousand seed weight, grain yield and harvest index were the important attributes used for data collection. Analysis of variance (ANOVA) for all parameters were computed with SAS 9.0 software and mean separation was done using least significance difference (LSD). The results of ANOVA analyses showed that sowing method of days to $50 \%$ emergence, days to $50 \%$ heading, days to $90 \%$ physiological maturity, total number of tillers per plant, number of effective tillers, thousand seed weight and number of spikelet's per panicle were significantly $(\mathrm{P}<0.05)$ influenced by the main effects of seeding rates and inter-row spacing, while plant population, plant height and grain yield were highly significantly $(\mathrm{P}<0.01)$ affected by the main effects of the seeding rates and inter-row spacing. Biomass and straw yields as well as harvest index were not significantly affected by seeding rates and inter-row spacing. Furthermore, the interaction effect plant population and grain yields were highly significantly $(\mathrm{P}<0.01)$, affected by seeding rates and inter-row spacing. While plant height, biomass yield and thousand seed weight were significant $(\mathrm{P}<0.05)$ influenced. In general, the present study investigated under sowing methods of grain yield was gained $25.75 \%$ over all the treatments. Sowing method of seeding rate of $5 \mathrm{~kg} / \mathrm{ha}$ and $25 \mathrm{~cm}$ of row spacing were found to be the best resourcefully advantageous over the rest treatments.
\end{abstract}

Keywords: Inter-row Spacing, Seed Rates, Tef and Yield Component

\section{Introduction}

Tef (Eragrostis tef (Zucc.) Trotter) is the most important and traditional staple cereal crop in Ethiopia and is grown extensively under various climatic and soil conditions. Currently, tef in Ethiopia is first rank in area of production (3.07 $\mathrm{M} \mathrm{ha}$ ) and second ranks in terms of production (5.4 M t) which followed by Maize. But it is productivity (1.17 t ha-1) is very low as compared with productivity of other grain cereal crops yield potential [9] [7], reported that tef is the staple food of most Ethiopian people, the present production system cannot satisfy the consumers demand. This is because that farmers use backward farming system which is not supported by modern technologies. A simple 
instance is that the local people use broadcasting system of seed sowing rather than using row method of sowing. According to [1], [8], reducing the high seeding rate from $25 \mathrm{~kg} / \mathrm{ha}$ which is widely used by the farmers in the broadcast method of sowing to low seeding rate $5 \mathrm{~kg} / \mathrm{ha}$ in the row method of sowing attributed to increase tef grain yield from $500-1200 \mathrm{~kg} / \mathrm{ha}$ to $3400-5100 \mathrm{~kg} / \mathrm{ha}$, respectively. In other words, the row method of sowing at much reduced rate of seeding would increase tef yield by four fold over that of broadcast method of sowing which is normally practiced by farmers at high seeding rate.

Reducing the seed rate to between 2.5 and $3 \mathrm{~kg}$ per hectare allows for reduced competition between seedlings and optimal tillering of the tef plants. By row planting the seeds, land management and especially weeding can also be done more readily and the incidence of lodging is reduced [10].

These beginning results of row method of tef sowing by themselves are not, however, the end solutions for the improvement of tef production in the country, for instances, there is no yet study for a concrete information available about the interaction of seeding rates with different inter-row spacing. Therefore, the present preliminary results of row sowing of tef should be verified from different angles and conditions as well as from technical and economical feasibilities prior to its wider dissemination and application by end users. The present study was hence conceived to evaluate the effects of different seeding rates and inter-row spacing of sowing method on growth and yield components of tef on the one hand and on economics of tef production on the other hand. The main objective of the present experiments was therefore to study the effect of seeding rates and inter-row spacing method of sowing on growth and yield components of tef.

\section{Materials and Methods}

\subsection{Description of the Study Area}

The study was conducted under rain fed condition during the main cropping season of 2013 in Jimman Kebele at Ebinat district. Ebinat district is located between $11^{\circ}$ and $12^{\circ}$ North latitude, and $37^{\circ}$ and $38^{\circ}$ East longitudes [5]. Ebinat is found about $687 \mathrm{~km} \& 120 \mathrm{~km}$ North of Addis Ababa and Bahir Dar, respectively. The mean annual rainfall is $600-800$ $\mathrm{mm}$, of which $90 \%$ occurs in the months of June to September. Rainfall in the district is erratic, and torrential with a unimodal pattern that starts at the end of May and lasts to mid-September. The monthly mean temperature is $18^{\circ} \mathrm{C}$ and the elevation of Ebinat District, wherein the experimental site found, is 2246 m.a.s.l. According to [5], reported that the topography of the district consists of gorges and rugged terrain (40\%), mountains (45\%), and plain land (15\%) and it is divided into three agro- climatic zones: Dega, (15\%), Weina-Dega, (35\%) and Kolla (50\%). Before, planting the composite soil sample was taken and analyzed in Bahir Dar Soil Laboratory to determine some physiochemical characters of the soil of the experimental site. The plot of land, which was used for the present trial, had been fertilized for the last over two years either with organic or mineral fertilizers. In addition, it was a millet field in the previous cropping season. The dominant crops in the areas are tef, wheat and barley is commonly grown.

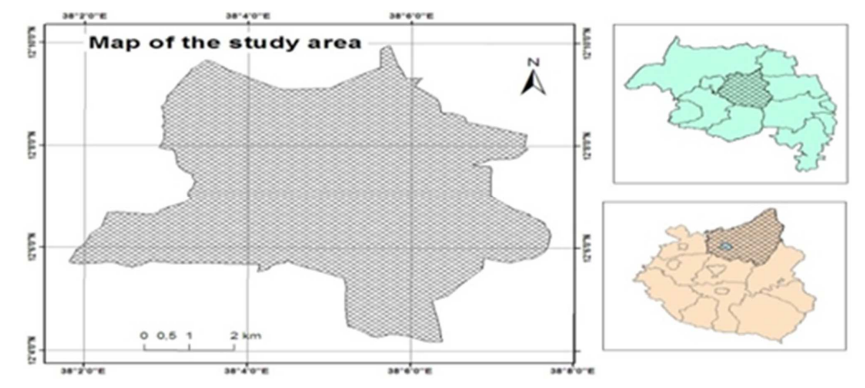

Study area of Ebinat Districts (Jimman Kebele)

Figure 1. Map of South Gondar, Ebinat Woreda and Jimman Kebele.

\subsection{Experimental Planting Materials}

Quencho (DZ-01-378) variety of tef was used as a planting material for the research study. Sowing was done on 19 June 2013. Seeding was done as per the treatments and design of the experiments. Nitrogen and Phosphorus fertilizers were applied as per blanket recommendation $(100 \quad \&$ $100 \mathrm{~kg} / \mathrm{ha}$ )(MOA pakages) respectively. DAP was applied at the time of sowing, while Urea was applied in split two times during the time of sowing and just before booting stage. Due to the frequent prevalence of vigorous growth and high infestation of weeds, the experimental plots were hand weeded three times after 25, 45 and 65 days of sowing.

During the experimentation, central shoot fly (Hylemyaarambourgi) infestation had been occur in the sets of the experimentations. The insect fed on leaves at the central tip and other succulent parts of the plant. The infestation was indeed treated by spraying of insecticide called Diazinon $60 \%$ liter per hectare of recommendation.

\subsection{Experimental Design and Treatments Procedures}

The research was consisted a set of experiments, namely the three seeding rates and three inter-row spacing of sowing method with factorial experiment. The 3 seeding rates $(5,7.5$ $\left.\& 10 \mathrm{~kg} \mathrm{ha}^{-1}\right)$ were combined with 3 inter-row spacing of (15, $20 \& 25 \mathrm{~cm})$ totally contained 9 treatments. The experiment was laid out in a randomized complete block design (RCBD) with three replications. Treatment combinations used for row sowing experiment was shown in Table 1. The experimental plot was indeed oxen plowed more than four times before subdividing into blocks and treatment plots. The plot size was $2 \mathrm{~m} \times 1 \mathrm{~m}\left(2 \mathrm{~m}^{2}\right)$. The blocks were separated by $1 \mathrm{~m}$, while treatment plots within blocks were separated by $0.75 \mathrm{~m}$ among treatments.

\subsection{Data Collection}

Data were collected in various growth and yield components from the inner part of each plot to the border 
effect. The net plot area was delineated by leaving one border row at both sides of every plots.

\subsubsection{Phenological Parameters}

Days to $50 \%$ emergence, days to $50 \%$ heading and days to $90 \%$ to maturity were recorded from sowing to at each standing of the plants in a plot.

\subsubsection{Growth Parameters}

Number of plants per $\mathrm{m} 2$, plant height, and number of tillers per plant, number of fertile tillers per plant, panicles length and number of panicles per plant were considered as growth parameters under the context of the present study.

\section{Plant Population}

Following plants were matured, they were counted using $0.25 \times 0.25 \mathrm{~m}$ quadrant measurements in a net plot area and among in the variable row spacing. Data of plant population were collected from net plot areas. Plant population varied as they were grown at different plant spacing and seed rates.

Plant height

The height of plants was determined by taken five randomly selected plants per plot in the net plot area and measuring their height from the ground level to the apex of the main stem at 50\% heading and $90 \%$ maturity with linear meter, and the average values in centimeter were used for further analysis.

Total Number of tillers

Tillers grown from the main stems were considered as primary tillers, while those tillers grown from the primary tillers were considered as secondary tillers. Both primary and secondary tillers were counted at $50 \%$ heading stage from five randomly selected plants from each net plot area..

Number of effective tillers

Fertile tillers per plant were recorded as the average number of tillers with panicle including the main shoot from five randomly selected tiller plants in a net plot area per plot.

Panicle length

Plant panicle length per plant was expressed in centimeters by measuring and averaging the height of five randomly taken plants from the stand point of heading plant to the apex of the main panicle matured at 90 percent growth stage.

Number of spikelet's per panicle

Number of spikelet's per panicle were recorded as the average number of spikelet's grown from the main shoot and from five randomly selected spikelet's per panicle in a net area per plot.

\subsubsection{Yield and Yield Related Traits}

\section{Thousand seed weight ( $\mathrm{mg}$ )}

Samples of 1000 seeds from each plot net area at a moisture content of $11 \%$ were taken and counted using the aid of magnified lens $(9 \mathrm{x})$ and weighed using a sensitive electrical balance. The seed counting, weighing and determination of the moisture content were done at Bahir Dar Seed Laboratory office.

Grain yield $(\mathrm{kg} / \mathrm{ha})$

Grain yield was harvested from the net plot areas. Plants in the net plot areas were harvested separately, and then carefully threshed on canvas. The straw was removed mechanically by hand, while the spikes were removed by winnowing. The clean grain of each plot was measured with sensitive electrical balance. The grain yield was adjusted to $11 \%$ moisture level for the corresponding dry weight of the $1000 \mathrm{~g}$ sample was taken. Grain yield of net plot areas were taken, and converted into $\mathrm{kg} / \mathrm{ha}$.

Biomass yield $(\mathrm{kg} / \mathrm{ha})$

Total dry biomass yield included both straw and grain weights were measured and converted into $\mathrm{kg}$ per hectare basis from the net plots.

Straw yield $(\mathrm{kg} / \mathrm{ha})$

Straw yield was obtained when grain yield subtracted from total aboveground biomass yield.

Harvest index

Harvest index (HI) was calculated as the ratio of grain yield to biomass yield.

Pest Infestation

Whenever pests occurred during the experimentation, their kinds and level of infestation were recorded at each plot level.

\subsection{Data Analysis}

The data collected from the experiments at different growth stages were subjected to analysis of variance as procedures described by Gomez and Gomez [10], SAS (Statistical Analysis Software) version 9.0 was used to analyze the ANOVA and GLM of all collected data. For variables showing significance differences, mean separation was made using least significance difference (LSD).

\section{Results and Discussion}

The results and major findings of this study conducted to determine the effect of sowing methods and seeding rates on growth and yield components of tef are presented and discussed in these session. The main and interaction effects of row spacing and seeding rates on growth and yield parameters are presented and discussed. Although the pest was controlled by spraying of Diazinon $60 \%$, central shoot fly infestation $17 \%$ was shown.

\subsection{Crop Phenology}

\section{Days to $50 \%$ emergence}

Emergence of seedlings were completed from 7-9 mean days after sowing. The row sowing of narrow spacing $(15 \mathrm{~cm})$ with higher seed rate $(10 \mathrm{~kg} / \mathrm{ha})$ hastens the emerging rate. But wider spacing of $(25 \mathrm{~cm})$ with lower seed rate of $(5 \mathrm{~kg} / \mathrm{ha})$ was germinated 7.89 mean days after sowing. The result shown that day to $50 \%$ emergence was significantly $(\mathrm{P}<0.05)$ influenced by different seeding rates. But it was not significantly affected by inter-row spacing and their interaction effect. In line with the results from this finding [11] revealed that the emergences of maize seedling among two methods of sowings were highly significant. 


\section{Days to $50 \%$ heading}

Days to $50 \%$ heading was significantly affected by seed rates $(\mathrm{P}<0.05)$ but it was not influenced by variable at row spacing and their interaction effect between seed rate and row spacing. Plants under higher seed rate with narrow spacing heading earlier than lower seed rate of a wider spacing (Table 1). The longest duration to head initiation was recorded under lower seed rate $(5 \mathrm{~kg} / \mathrm{ha})$ with wider row spacing $(25 \mathrm{~cm})$. Similarly, the present study, [4] reported that early flowering with an increase in the seed rate of tef.

Table 1. Main effects of row spacing and seeding rates on phenological parameters of tefin row sowing method.

\begin{tabular}{llll}
\hline Treatment & DTE & DTH & DTM \\
\hline Row spacing $(\mathrm{cm})$ & & & \\
15 & 7.67 & 61.89 & 97.22 \\
20 & 7.89 & 62.00 & 97.22 \\
25 & 8.11 & 61.89 & 97.44 \\
MEAN & 7.89 & 61.93 & 97.30 \\
MSE+ & 1.3608 & 1.3193 & 1.5275 \\
LSD at (0.05) & $\mathrm{ns}$ & $\mathrm{ns}$ & $\mathrm{ns}$ \\
Significance level & & & \\
Seeding rate (kg/ha) & & & \\
5 & $8.67^{\mathrm{a}}$ & $62.67^{\mathrm{a}}$ & $98.00^{\mathrm{a}}$ \\
7.5 & $7.78^{\mathrm{ab}}$ & $61.89^{\mathrm{ab}}$ & $97.44^{\mathrm{ab}}$ \\
10 & $7.22^{\mathrm{b}}$ & $61.22^{\mathrm{b}}$ & $96.44^{\mathrm{b}}$ \\
MEAN & 7.89 & 61.93 & 97.30 \\
MSE+ & 1.3608 & 1.3193 & 1.5275 \\
LSD at (0.05) & 1.3477 & 1.3067 & 1.5128 \\
Significance level & $*$ & $*$ & $*$ \\
CV (\%) & 17.2499 & 2.3177 & 1.6550 \\
\hline
\end{tabular}

Table 2. Interaction effects of row spacing and seeding rates on phonological parameters teff in row planting method.

\begin{tabular}{llll}
\hline $\begin{array}{l}\text { Seed rate } \mathbf{( k g} / \mathbf{h a}) \times \text { Row } \\
\text { spacing }(\mathbf{c m})\end{array}$ & DTE & DTH & DTM \\
\hline $5 \times 15$ & 8.33 & 62.33 & 98.33 \\
$5 \times 20$ & 9.00 & 63.00 & 98.00 \\
$5 \times 25$ & 8.66 & 62.66 & 97.66 \\
$7.5 \times 15$ & 7.66 & 62.33 & 96.66 \\
$7.5 \times 20$ & 7.00 & 61.33 & 97.66 \\
$7.5 \times 25$ & 8.66 & 62.00 & 98.00 \\
$10 \times 15$ & 7.00 & 61.00 & 96.66 \\
$10 \times 20$ & 7.66 & 61.66 & 96.00 \\
$10 \times 25$ & 7.00 & 61.00 & 96.66 \\
MEAN & 7.89 & 61.93 & 97.30 \\
MSE + & 1.3608 & 1.3193 & 1.5275 \\
LSD $(0.05)$ & $n s$ & $n s$ & $n s$ \\
CV & 17.2499 & 2.1305 & 1.5699 \\
\hline
\end{tabular}

Value Means with the same letter are not significantly different

key; - DTE $=$ days to $50 \%$ emergence, $\mathrm{DTH}=$ Days to $50 \%$ heading and DTM= Days to $90 \%$ physiological maturity ', $*$ ', ' $* *$ ' and ns were $0.05,0.001$ significance, highly significance and non significance level respectively.

\section{Days to $90 \%$ physiological maturity}

Main effects of seed rates under row sowing was significantly differences $(\mathrm{p}<0.05)$ but row spacing and their interaction effect of all treatments were not significantly affected $(\mathrm{p}<0.05)$. Similarly, days to $50 \%$ heading, the maximum days to $90 \%$ physiological maturity were recorded under lower seed rate with wider row spacing. Likewise to the present results, [6] reported that increasing levels of seed rate promoted early physiological maturity of rice.

\subsection{Growth Parameters}

\section{Plant population}

Plant populations were Significant differences $(\mathrm{p}<0.01)$ and $(\mathrm{p}<0.05)$ both row spacing and seed rates and their interaction effects (Table 3 ). Stand count varied as they were grown at different plant spacing's and seed rates (15, 20 and $25 \mathrm{~cm})$ and $(5,7.5$ and $10 \mathrm{~kg} / \mathrm{ha})$ under row sowing respectively. Higher mean Plants counts under row sowing, particularly Rate of stand from the narrow row spacing with higher seed rate $(15 \mathrm{~cm} \times 10 \mathrm{~kg} / \mathrm{ha})$ exceeded, that of the wide row spacing and lower seed rate $(25 \mathrm{~cm} * 5 \mathrm{~kg} / \mathrm{ha})$ by $64 \%$. Confirm to the present finding, [12] reported that final plant population of grain amaranth at harvest indicated increasing plant mortality as plant population increased. Also similarly to the result found [9], reported that reduced inter plant competition and plant mortality were observed at the lowest plant population, compared with the higher plant population.

Plant height

Plant height at physiological maturity was highly significantly affected by seeding rates $(\mathrm{P}<0.01)$ and $(\mathrm{p}<0.05)$ and their interaction effect respectively. But it was not affected by inter-row spacing (Table 4). Higher plant height $(120 \mathrm{~cm})$ was recorded in row sowing at a lower seed rate $(5 \mathrm{~kg} / \mathrm{ha})$. While the lowest plant height $(110 \mathrm{~cm})$ was obtained at the higher seeding rate $(10 \mathrm{~kg} / \mathrm{ha})$. Studies shown under rainfed condition, wider row spacing $(25 \mathrm{~cm})$ recorded higher Plant height, ear length, ear weight, number of grains per panicle and 1000-grain weight in wheat [3], reported that plant height of wheat was significantly affected by seeding rates and row spacing.

Panicle length

Main effects of Panicle length was highly significantly affected $(p<0.01)$ by seeding rates (Table 3$)$. But it was not significantly difference by inter-row spacing and the interaction effect (Table 4). Higher panicle length $(43 \mathrm{~cm})$ was recorded in row planting at a lower seed rate $(5 \mathrm{~kg} / \mathrm{ha})$. The lowest panicle length $(40 \mathrm{~cm})$ was given at a higher seed rates $(10 \mathrm{~kg} / \mathrm{ha})$ in row sowing. Agreement with the present consequence, [4] reported significantly higher panicle length under row sowing than in broadcast sowing. Thus, application of adequate amount and efficient utilization of nutrients leads to high photosynthetic efficiency and accumulation of high dry matter which ultimately increases panicle length and yield. Panicle length is one of the yield attributes of tef which contributes to high grain, straw and biomass yield. Also similarly to the present found [4] reported positive and highly significant correlation of panicle length with culm length, plant length, and number of internodes and grain yield. 
Table 3. Main effects of row spacing and seeding rates on growth parameters of teff in row planting method.

\begin{tabular}{|c|c|c|c|c|c|c|}
\hline Treatment & PP $\mathbf{n} / \mathbf{m} 2$ & TNT & NFT & PH (cm) & PAL (cm) & NPA \\
\hline \multicolumn{7}{|l|}{ Row spacing $(\mathrm{cm})$} \\
\hline 15 & $58.07^{\mathrm{a}}$ & $8.08^{\mathrm{b}}$ & $6.62^{\mathrm{b}}$ & 113.91 & 40.86 & 30.60 \\
\hline 20 & $46.76^{b}$ & $8.46^{\mathrm{b}}$ & $6.98^{\mathrm{b}}$ & 113.71 & 41.54 & 31.93 \\
\hline 25 & $36.88^{\mathrm{b}}$ & $11.20^{\mathrm{a}}$ & $9.80^{\mathrm{a}}$ & 118.11 & 42.42 & 32.09 \\
\hline MEAN & 47.24 & 9.25 & 7.80 & 115.24 & 41.60 & 31.54 \\
\hline MSE+ & 54.47 & 2.4641 & 2.4308 & 4.7096 & 1.7217 & 2.3508 \\
\hline LSD at $(0.05)$ & 73.912 & 2.4405 & 2.4074 & ns & ns & ns \\
\hline Significance level & ** & * & * & & & \\
\hline \multicolumn{7}{|l|}{ Seed rate $(\mathrm{kg} / \mathrm{ha})$} \\
\hline 5 & $41.78^{\mathrm{ab}}$ & 10.81 & 8.88 & $119.67^{\mathrm{a}}$ & $43.40 \mathrm{a}$ & $33.34^{\mathrm{a}}$ \\
\hline 7.5 & $45.16^{\mathrm{b}}$ & 8.54 & 7.12 & $115.83^{\mathrm{ab}}$ & $40.81^{\mathrm{b}}$ & $30.93^{\mathrm{b}}$ \\
\hline 10 & $54.76^{\mathrm{a}}$ & 8.89 & 7.40 & $110.23^{\mathrm{b}}$ & $40.61^{\mathrm{b}}$ & $30.31^{\mathrm{b}}$ \\
\hline MEAN & 47.24 & 9.25 & 7.80 & 115.24 & 41.60 & 31.54 \\
\hline MSE+ & 54.47 & 2.4405 & 2.4308 & 4.70 .96 & 1.7217 & 2.3508 \\
\hline LSD at $(0.05)$ & 53.947 & ns & ns & 6.3965 & 2.3363 & 2.3282 \\
\hline Significance deference & * & & & $* *$ & $* *$ & * \\
\hline CV $(\%)$ & 22.8793 & 26.6532 & 31.1644 & 4.0866 & 4.1381 & 7.4532 \\
\hline
\end{tabular}

Table 4. Interaction effects of row spacing and seed rates on growth parameters of teff in row planting method.

\begin{tabular}{|c|c|c|c|c|c|c|}
\hline Seed rate $(\mathrm{kg} / \mathrm{ha}) \times$ xow spacing $(\mathrm{cm})$ & PP_n/m2 & TNT & NFT & PH (cm) & PL (cm) & NSL \\
\hline $5 * 15$ & $58.24^{\mathrm{ab}}$ & 9.43 & 7.96 & $111.40^{\mathrm{ab}}$ & 40.46 & $32.10^{\mathrm{ab}}$ \\
\hline $5 * 20$ & $42.43^{\mathrm{ab}}$ & 10.30 & 7.10 & $113.36^{\mathrm{ab}}$ & 41.00 & $33.33^{\mathrm{ab}}$ \\
\hline $5 * 25$ & $34.84^{\mathrm{b}}$ & 11.16 & 9.36 & $119.30^{\mathrm{a}}$ & 42.26 & $34.70^{\mathrm{a}}$ \\
\hline $7.5 * 15$ & $49.85^{\mathrm{ab}}$ & 7.50 & 6.26 & $111.30^{\mathrm{ab}}$ & 39.56 & $29.83^{b}$ \\
\hline $7.5 * 20$ & $40.43^{b}$ & 9.79 & 7.70 & $117.73^{\mathrm{ab}}$ & 42.46 & $31.80^{\mathrm{ab}}$ \\
\hline $7.5 * 25$ & $35.07^{\mathrm{b}}$ & 9.24 & 7.43 & $110.60^{\mathrm{ab}}$ & 40.90 & $31.16^{\mathrm{ab}}$ \\
\hline $10 * 15$ & $66.12^{\mathrm{a}}$ & 8.63 & 6.76 & $112.50^{\mathrm{ab}}$ & 40.26 & $29.86^{\mathrm{b}}$ \\
\hline $10 * 20$ & $57.43^{\mathrm{ab}}$ & 10.36 & 8.03 & $108.93^{\mathrm{b}}$ & 39.40 & $30.66^{\mathrm{b}}$ \\
\hline $10 * 25$ & $40.74^{\mathrm{ab}}$ & 8.26 & 7.43 & $111.73^{\mathrm{ab}}$ & 40.56 & $30.40^{\mathrm{b}}$ \\
\hline MEAN & 47.74 & 9.41 & 7.56 & 112.99 & 40.77 & 31.54 \\
\hline MSE+ & 54.4708 & 3.0864 & 2.1056 & 5.1732 & 2.1286 & 2.3508 \\
\hline $\operatorname{LSD}(0.05)$ & 128.02 & ns & $\mathrm{ns}$ & 8.8742 & $\mathrm{~ns}$ & 4.0326 \\
\hline Significance level & ** & & & * & & * \\
\hline $\mathrm{CV}$ & 22.8793 & 32.7956 & 27.8414 & 4.5787 & 5.2215 & 7.4532 \\
\hline
\end{tabular}

KEY: - PP_n= Plant population per $\mathrm{m} 2, \mathrm{TNT}=$ total number of tiller, NFT $=$ number of fertile tiller, $\mathrm{PH}=$ plant height, $\mathrm{PL}=$ panicle length, $\mathrm{NSL}=$ number of spikelet's, *** and NS were $0.05,0.01$ significance level and non significance respectively. Value Means with the same letter are not significantly different

\section{Total number of tillers per plant}

Total number of tillers at physiological maturity were significantly affected $(\mathrm{P}<0.05)$ by sowing method of interrow spacing. But, it were not significantly affected by at seeding rates (Table 4) and also it was not affected by their interaction effect at both seed rates and inter-row spacing (Table 5). The higher numbers of tillers (11.20) were recorded in wider row spacing of $(25 \mathrm{~cm})$ and lower seed rates of $5 \mathrm{~kg} / \mathrm{ha}$. Whereas the lowest tiller numbers (8) were recorded in a closure row spacing and higher seed rates of $(15 \mathrm{~cm} * 10 \mathrm{~kg} / \mathrm{ha})($ Table 4$)$. In line with the results found, [7] reported that the increased spacing, increased tiller number and fertile tiller culms, and increased the number of seeds/panicle of tef.

\section{Number of effective tiller}

The number of effective tillers counted at $90 \%$ physiological maturity was significantly $(\mathrm{p} \leq 0.05)$ affected by the main effects of inter-row spacing under row sowing method (Table 4). But it was not significantly affected $(\mathrm{p}<0.05)$ seed rate and their interactions effect (Tables 4 \&
5). The wider inter-row spacing of $(25 \mathrm{~cm})$ significantly higher number of effective tillers (10/plant) followed by seed rate at $15 \mathrm{~cm}$ (7/plant) exceed by $43 \%$ (Table 4$)$. Similar to the present study, [2] reported that wider planted rice achieved a higher yield than closure once because of more tillers per plant and productivity of each tiller.

Number of spikelet's per panicle

Number of spikelets per panicle was significantly affected $(p<0.05)$ by seeding rates and their interaction effect. But, it was not affected by inter- row spacing among treatment combination in row sowing (Tables $3 \& 4$ ). The results showed that the numbers of spikelet's per panicle increased significantly with increasing lower seeding rates. The highest number of spikelet's per panicle (33.34spikelets/plant) was recorded at $5 \mathrm{~kg} / \mathrm{ha}$, whereas, the lowest spikelet's per panicle (30.31 panicle/plant) was shown at the highest seed rate at $10 \mathrm{~kg} / \mathrm{ha}$. This finding is in line with the reports [13] who found that the number of spikes per hill showed a significant difference between row spacing's used in rice crop. 
Table 5. Main effects of row spacing and seed rates on yield parameters of tef.

\begin{tabular}{|c|c|c|c|c|c|}
\hline Treatment & BMY (kg/ha) & SRY (kg/ha) & TSW (mg) & GY (kg/ha) & HI \\
\hline \multicolumn{6}{|l|}{ Row spacing $(\mathrm{cm})$} \\
\hline 15 & 8580.00 & 6276.19 & 401.33 & $2303.818^{\mathrm{b}}$ & 0.268 \\
\hline 20 & 8436.21 & 5986.93 & 380.89 & $2449.279^{\mathrm{b}}$ & 0.283 \\
\hline 25 & 9523.80 & 6779.30 & 407.00 & $2744.508^{\mathrm{a}}$ & 0.278 \\
\hline MEAN & 8846.67 & 6439.39 & 396.40 & 2465.36 & 0.2768 \\
\hline MSE+ & 1194.465 & 1202.446 & 39.2759 & 133.4999 & 0.0437 \\
\hline LSD at $(0.05)$ & $\mathrm{ns}$ & ns & $\mathrm{ns}$ & 174.45 & ns \\
\hline Significance level & & & & $* *$ & \\
\hline \multicolumn{6}{|l|}{ Seed rate $(\mathrm{kg} / \mathrm{ha})$} \\
\hline 5 & 9181.81 & 6665.16 & $422.33^{\mathrm{a}}$ & $2631.20^{\mathrm{a}}$ & 0.278 \\
\hline 7.5 & 8660.23 & 6286.90 & $392.33^{\mathrm{ab}}$ & $2433.02^{b}$ & 0.279 \\
\hline 10 & 8697.98 & 6366.13 & $374.56^{\mathrm{b}}$ & $2331.86^{\mathrm{b}}$ & 0.271 \\
\hline MEAN & 8846.67 & 6439.39 & 396.40 & 2465.36 & 0.277 \\
\hline MSE+ & 1194.465 & 1202.446 & 39.2759 & 133.4999 & 0.0437 \\
\hline LSD at $(0.05)$ & $\mathrm{ns}$ & ns & $38 . .90$ & 132.22 & NS \\
\hline Significance level & & & $*$ & $* *$ & \\
\hline $\mathrm{CV}(\%)$ & 13.5018 & 18.6732 & 9.9080 & 5.1441 & 15.7798 \\
\hline
\end{tabular}

Table 6. Interaction effects of row spacing and seeding rates on yield parameters of tef.

\begin{tabular}{|c|c|c|c|c|c|}
\hline Seed rate $(\mathrm{kg} / \mathrm{ha}) \times$ Row spacing $(\mathrm{cm})$ & BY (kg/ha) & SRY (kg/ha) & TSW (mg) & GY (kg/ha) & HI \\
\hline $5 \times 15$ & $8236.8^{\mathrm{b}}$ & 5920 & $404.00^{\mathrm{ab}}$ & $2316.9^{\text {cd }}$ & 0.281 \\
\hline $5 \times 20$ & $8642.0^{\mathrm{ab}}$ & 6050 & $414.67^{\mathrm{ab}}$ & $2592.0^{\mathrm{bc}}$ & 0.311 \\
\hline $5 \times 25$ & $10666.7^{\mathrm{a}}$ & 7622 & $448.33^{\mathrm{a}}$ & $3045.0^{\mathrm{a}}$ & 0.287 \\
\hline $7.5 \times 15$ & $9266.4^{\mathrm{ab}}$ & 6933 & $413.67^{\mathrm{ab}}$ & $2333.1^{\text {cd }}$ & 0.252 \\
\hline $7.5 \times 20$ & $8333.3^{b}$ & 5982 & $369.67^{b}$ & $2350.9^{\text {cd }}$ & 0.285 \\
\hline $7.5 \times 25$ & $8381.0^{\mathrm{b}}$ & 5676 & $393.67^{\mathrm{ab}}$ & $2705.1^{\mathrm{b}}$ & 0.331 \\
\hline $10 \times 15$ & $8236.8^{b}$ & 5975 & $386.33^{\mathrm{ab}}$ & $2261.5^{\mathrm{d}}$ & 0.279 \\
\hline $10 \times 20$ & $8333.3^{b}$ & 5928 & $358.33^{b}$ & $2404.9^{\mathrm{bcd}}$ & 0.292 \\
\hline $10 \times 25$ & $9523.8^{\mathrm{ab}}$ & 7040 & $379.00^{\mathrm{b}}$ & $2483.4^{\text {bcd }}$ & 0.264 \\
\hline MEAN & 8846.68 & 6347.48 & 396.41 & 2499.20 & 0.287 \\
\hline MSE+ & 1194.486 & 1227.48 & 39.2758 & 128.5628 & 0.0476 \\
\hline LSD (0.05) & 2049 & ns & 67.374 & 302.15 & ns \\
\hline Significance level & $*$ & & $*$ & $* *$ & \\
\hline $\mathrm{CV}$ & 13.5018 & 19.3380 & 9.9079 & 5.1441 & 16.5649 \\
\hline
\end{tabular}

Value Means with the same letter are not significantly different

key:-BY= biomass yield, $\mathrm{SRY}=$ straw yield, TSW= thousand seed weight, $\mathrm{GY}=$ grain yield and $\mathrm{HI}=$ harvest index, * ** and $\mathrm{NS}$ were $0.05,0.01$ significance level and non significance respectively.

\subsection{Vield and Vield Components}

\section{Biomass and straw yield}

Main effect of both biomass and Straw yield were not significantly affected $(p<0.05)$ by inter-row spacing and seeding rates (Table 5). But only biomass yield was significantly $(\mathrm{p}<0.05)$ affected by interaction effect among treatment (Table 6). The present study found to confirm [12] plant height was significantly affected by the main effect of row spacing, but grain yield, biomass yield, harvest index and final plant population were not affected.

Thousand Seed weight (mg)

Weight of 1000 -seeds was not significantly $(p<0.05)$ affected by row spacing within the treatments. But, it was affected $(p<0.05)$ by main effect of seeding rates and interaction effect along with treatments (Tables 5 \& 6). Highest weight of thousand seed $(422 \mathrm{mg}$ ) was recorded the decreasing seeding rate $(5 \mathrm{~kg} / \mathrm{ha})$. These results are in conformity [14] who reported that 1000 grain weight decreased with increasing in seeding densities.

Grain yield $(\mathrm{kg} / \mathrm{ha})$

Grain yield was highly significantly $(\mathrm{P}<0.01)$ affected by sowing methods of seeding rates, row spacing and their interaction effect among the treatments (Tables $5 \& 6$ ). A sowing method of inter-row spacing and seeding rates at 5 $\mathrm{kg} / \mathrm{ha}$ and $25 \mathrm{~cm}$ gave significantly higher $(3045 \mathrm{~kg} / \mathrm{ha})$ grain yield than the increasing row spacing and seeding rates (Table 6). Also lower grain yield was recorded (2261/ha) under higher seeding rates of $(10 \mathrm{~kg} / \mathrm{ha})$ and closure row spacing of $(15 \mathrm{~cm})$. Grain yield increased with an increase in inter-row spacing and decreases seeding rates (Tables $5 \& 6$ ). Sowing method of tef with reduced seeding rates showed an increased $25.75 \%$ grain yield over the higher seeding rate. This might be due to the fact that longer panicle length (more grain number per panicle), much more number of effective tillers and lower lodging effect than the higher seeding rates which are directly related to grain yield.. similar studies shown to the present findings, [4] reported that a significant increased in yield components of tef with decreased seed rates. Similar studies were found the present results, [4] reported that there was significant increase in yield components of tef with decreased seed rates from highest to lowest $(35,30,25,20$, kgha-1)..

Harvest index 
Harvest indexes were not significantly $(\mathrm{p}<0.05)$ affected at main effects of seeding rates and row spacing and their interaction (Tables $5 \& 6$ ). The analysis shown that there was no occurred a significant variation on harvest index. This might be due to the higher grain yield obtained at inter-row spacing and seeding rates $(15 \mathrm{~cm}, 20 \mathrm{~cm}$ and $25 \mathrm{~cm})$ and $(5$, 7.5 and $10 \mathrm{~kg} / \mathrm{ha}$ ) respectively. Confirmation to the present results found [12] plant height was significantly affected by the main effect of row spacing, but grain yield, biomass yield, harvest index and final plant population were not significantly affected.

\section{Conclusion and Recommendation}

Field experiment was conducted in Ebinat Districts, South Gondar, Ethiopia to determine Effect of Sowing Methods of inter row spacing and Seeding Rates on Growth, yield and Yield Components of Tef. Among the inventiveness major findings of the experiment were days to $50 \%$ emergence, $50 \%$ days to heading; days to $90 \%$ physiological maturity; plant height, panicle length, biomass yield and straw yield, 1000 seed weight and harvest index were not significantly affected by inter-row spacing. But days to $90 \%$ physiological maturity, panicle length, 1000 seed weight and grain yield were significantly affected by seeding rates in row sowing. On the other hand, Days to $50 \%$ emergence, $50 \%$ days to heading, stand count, plant height and grain yield were affected by inter-row spacing and seeding rates. Significant variations were recorded in stand count per plot, number of tiller, number of fertile tiller and grain yield, under the main effects of inter-row spacing. While the interaction effects of inter-row spacing and seeding rates were significantly affected stand count, plant height, biomass yield, thousand seed weight and grain yield were affected in row sowing. Wider inter-row spacing of $25 \mathrm{~cm}$ and lower seeding rates of $5 \mathrm{~kg} / \mathrm{ha}$ caused, higher values of number of plant height $(119.30 \mathrm{~cm})$, biomass yield $(10666 \mathrm{~kg} / \mathrm{ha})$, thousand seed weight $(448 \mathrm{mg})$ and grain yield $(3045 \mathrm{~kg} / \mathrm{ha})$ as compared with the results of closure inter-row spacing $(15 \mathrm{~cm})$ and $(10 \mathrm{~kg} / \mathrm{ha})$ seeding rates which leads to have gained values of $112.5 \mathrm{~cm}, 29.8,8236 \mathrm{~kg} / \mathrm{ha}, 358 \mathrm{mg}, 2261.5 \mathrm{~kg} / \mathrm{ha}$ respectively, In general, the study was investigated under the sowing methods yield gained $25.75 \%$ of seeding rates of $5 \mathrm{~kg} / \mathrm{ha}$ and $25 \mathrm{~cm}$ of row spacing were found to be the best resourceful advantageous over the treatments. However, this tentative generalization has been based on a season at one location, required confirmation with further, similar and detailed studies for more seasons and at various locations are recommend and follow-up appropriately to determine sowing methods of row spacing and seed rates appropriately to approve the economic feasibility of tef experimental trials.

\section{Acknowledgements}

The authors kindly acknowledged to Bahir Dar and Debre Tabor University, Agricultural Transformation Agency (ATA) and Amhara Regional state of Berea of Agriculture (BOA) supporting financially and technically for successfully the research work.

\section{References}

[1] Berhe et al. Tareke (2008), best results came from spacing and row sowing increases tiller.

[2] Hoshikawa, v., 1984. A high yield produced through the extremely thin density of rice planting. Sci. J. Shiga Prof. Coll. 25: 45-51.

[3] Kakar, K. M., Arif and S. Ali, 2001. Effect of NP levels, seeding rates and row spacing on wheat. Pakistan Journal of Biological Science. 4 (11): 1319-1322 Kalgani Publication, New Delhi, pp. 23-57.

[4] Mitiku Melaku, 2008. Effects of seeding and nitrogen rates on yield and yield components of tef Eragrostistef (Zucc) Trotter. M.Sc. Thesis, Haramaya University, Ethiopia.

[5] SERA. 2000. Vulnerability Profile: Summary. Prepared with support from: Disaster Prevention and Preparedness Commission (DPPC) United States Agency for International Development (USAID) (SOAG 663.0021.00). Ebinat Woreda (district), South Gondar Zone, Amhara Region, pp. 1-5.

[6] Sewenet Ashebir, 2005. Effects of nitrogen and seed rates on grain yield components and nitrogen up take of rain fed rice (Oryza sativa) in Fogera, South Gonder. A M.Sc. Thesis presented to School of Graduate Studies of Haramaya University. pp. 5-37.1021-1041.

[7] Tareke Berhe and Nigusse Zena (2008). Results in a trial of system of teff intensification (STI) at debrezeit, Ethiopia.

[8] Tareke Berhe, then Director, Crops Productivity. Sasakawa Africa... In early 2008 the author, received a grant of USD 13,000 for exploratory research in tef.

[9] Central Statistical Agency (CSA), 2012. Agricultural sample survey 2007/2008. Report on Statistical Bulletin, 417. Addis Ababa, Ethiopia. 45 pp.

[10] Gomez, K. A. and Gomez, A. A. 1984. Statistical Procedures for Agricultural Research. 2nd ed. John Wiley \& Sons, New York. 1-680.

[11] Sheikh, K., K. S. Memon, M. Memon, and M. S. Akhtar. 2007. Changes in Mineral Composition and Bioavailable Potassium under Long-Term Fertilizer Use in Cotton-Wheat System. Soil Environ. 26: 1-9.

[12] Henderson, T. L., Johnson, B. L., Schneiter, A. A., 2000. New crops row spacing, plant population, and cultivar effects on grain amaranth in the Northern Great Plains. Agron. J., 92, 329-336.

[13] Buri Mohammed Moro, Issaka Roland Nuhu and Essien Ato Martin. 2016. Effect of Spacing on Grain Yield and Yield Attributes of Three Rice (Oryza sativa L.) Varieties Grown in Rain-fed Lowland Ecosystem in Ghana. International Journal of Plant \& Soil Science. 9 (3): 1-10, 2016; Article no. IJPSS. 21911.

[14] Marwat, A. Q., S. K. Khalil, A. L. Wazir and M. Iqbal. 1989. Effect of land preparation and seeding rates on plant height and straw yield on wheat. Sarhad J. Agric. 5 (3): 273-278. 